\title{
A gap analysis of farm tourism microentrepreneurial mentoring needs in North Carolina, USA
}

\author{
Bruno Ferreira ${ }^{a *}$ \\ Arizona State University \\ Duarte B. Morais ${ }^{b}$ and Adriana Szabo ${ }^{c}$ \\ North Carolina State University \\ Becky Bowen ${ }^{\mathrm{d}}$ and Susan Jakes ${ }^{\mathrm{e}}$ \\ NC State Extension \\ North Carolina State University
}

Submitted December 1, 2019 / Revised August 27, September 17, and October 6, 2020 /

Accepted October 8, 2020 / Published online November 4, 2020

Citation: Ferreira, B., Morais, D. B., Szabo, A., Bowen, B., \& Jakes, S. (2020). A gap analysis of farm tourism microentrepreneurial mentoring needs in North Carolina, USA. Journal of Agriculture, Food

Systems, and Community Development, 10(1), 83-99. https://doi.org/10.5304/jafscd.2020.101.025

Copyright (C) 2020 by the Authors. Published by the Lyson Center for Civic Agriculture and Food Systems. Open access under CC-BY license.

\begin{abstract}
Tourism is frequently proposed as a strategy to revitalize rural economies. The current mushrooming of web platforms for the tourism sharing economy affords rural microentrepreneurs opportunities to capitalize on the growing demand for authentic experiences. However, these platforms

a * Corresponding author: Bruno Ferreira, Assistant Professor, Tourism Development and Management, School of Community Resources and Development, Arizona State University; Phoenix, AZ 85004 USA; $\underline{\text { bsimoesf@asu.edu }}$

${ }^{b}$ Duarte B. Morais, Associate Professor, Equitable and Sustainable Tourism, Department of Parks, Recreation and Tourism Management, North Carolina State University; Raleigh, NC 27695 USA; dbmorais@ncsu.edu

c Adriana Szabo, Doctoral Candidate in Sociology (Food \& Environment), Department of Sociology and Anthropology, North Carolina State University; Raleigh, NC 27695 USA; aszabo@,ncsu.edu
\end{abstract}

may actually be widening the socio-economic gap between individuals across the digital and urban/ rural divides. In addition, the well-established urban culture of entrepreneurial mentorship is not taking hold in the rural areas, which direly need to attract and support nascent entrepreneurs. Farms are increasingly adopting tourism to diversify their business models, and Extension agents are trusted mentors par excellence of agribusiness entrepre-

d Becky Bowen, Project Manager, Cultivate NC, Community and Rural Development, NC State Extension, North Carolina State University; Raleigh, NC 27695 USA; +1-919-628-4317; blbowen@,ncsu.edu

e Susan Jakes, Associate State Program Leader of Community Development, NC State Extension, North Carolina State University; Raleigh, NC 27695 USA; susan_jakes@,ncsu.edu

\section{Funding Disclosure}

This study was partly funded by the Southeast States Chapter of the Travel and Tourism Research Association (SETTRA). 
neurs; therefore, this study explores the extent to which Extension agents feel able to address the mentoring needs of farm tourism microentrepreneurs. We measured both tourism e-microentrepreneurial self-efficacy (TeMSE) among farmers and tourism e-microentrepreneurial mentoring selfefficacy (TeMMSE) of Extension agents. Results show that farmers have relatively low self-efficacy in the dimensions of e-marketing and marshalling resources, and that agents may be efficacious mentors in these dimensions. Farmers also show low self-efficacy in adapting to externalities; however, agents do not perceive themselves as efficacious mentors in this dimension. We conclude with a discussion of practical implications for train-thetrainer strategies to enable farm tourism microentrepreneurship success.

\section{Keywords}

Agritourism, Farm Tourism, Entrepreneurial SelfEfficacy, Microentrepreneurship, Food Systems

\section{Introduction}

Tourism has been employed globally to revitalize rural economies by leveraging natural resources, cultural heritage, or the appeal of local champions who strive to share their passions with visitors. This is matched by a growing demand for authentic, unscripted experiences by hyperconnected urbanites and fueled by the current mushrooming of the tourism sharing economy (Organization for Economic Cooperation and Development [OECD], 2016) and web platforms like Airbnb, HipCamp, and HarvestHost. Tourism microentrepreneurs who provide experiences, food, lodging, or transportation now have the ability to bypass retail monopolies and mitigate information imbalances by making their services and products directly available to potential visitors (Ditta-Apichai, Kattiyapornpong, \& Gretzel, 2020). However, there are concerns that the advent of web-based sharing economy platforms may be widening the socio-economic gap between individuals across the digital divide by excluding microentrepreneurs with unreliable access to the internet and limited computer skills (Morais et al, 2012; Payton, Morais \& Heath, 2015). In addition, they may show low efficacy in other domains of entrepreneurial activity that may preclude them from investing themselves in entrepreneurial opportunities (Ferreira, Morais, Pollack, \& Bunds, 2018).

Whereas the culture of mentorship is wellestablished in the urban incubator-accelerator techentrepreneurship context, there is limited evidence that such a culture is taking hold in rural areas that so direly need to attract and support nascent entrepreneurs (Halim, 2016, Hustedde, 2018; OECD, 2003). Frequently, Extension agents are trusted mentors of agribusiness entrepreneurs, and farming businesses are increasingly adopting tourism as a component of their business model; therefore, this study explores the extent to which rural development Extension agents in North Carolina feel able to mentor farmers wishing to start or add value to an existing farm tourism microbusiness. We first measured tourism microentrepreneurial selfefficacy (Ferreira et al., 2018) among 29 farmers in North Carolina. Secondly, we adapted this scale to assess Extension agents' tourism e-microentrepreneurial mentoring self-efficacy (TeMMSE). Third, we did a paper-based pilot test with 24 agents participating in a statewide Extension conference. Fourth, after incorporating feedback from the pilot, we surveyed 54 agents in North Carolina selfidentified as being involved in advising farm tourism microentrepreneurs. Finally, we plotted the data from both the farmer and agent samples on a bidimensional matrix and compared the relative location of each pair of datapoints: the farmers' TeMSE versus the agents TeMMSE. Results show that agents may be efficacious mentors in the dimensions of e-marketing and marshalling resources, but not in adapting to externalities, which may require a train-the-trainer approach to close the gap between the agents' capabilities and the farmers' needs.

\section{Literature Review}

\section{Rural Tourism and Agritourism}

Tourism has been a major force in the rejuvenation of depressed rural areas, which have been plagued by distinct although related problems such as population decline, disinvestment, industrialization, and urbanization (Carneiro, Lima, \& Silva, 2018; Cunha, Kastenholz, \& Carneiro, 2011; Lane, 1994; 
Sharpley \& Sharpley, 1997). According to Lane (1994), defining rural tourism simply as "tourism which takes place in the countryside" (p. 9) detracts from its multifaceted character and inherently and erroneously assumes rural areas are static and immune to urban influence. Accordingly, rural tourism has taken many forms and has served many purposes around the world, in the social, environmental, and economic spheres. For example, in Japan, "green tourism" in the Kunisaki Peninsula has contributed to raising public awareness and gaining political support for the preservation of a communal system of reservoirs that had been the backbone of local agriculture for centuries until urban exodus and industrialization sent the system into disarray (Vafadari, 2013). In South Africa, rural tourism was traditionally a "white man thing" that accounted for almost the totality of demand and supply and was for the most part a synonym of wildlife tourism; eventually it branched out into adventure tourism, cultural tourism, and 'township tourism,' which has created economic opportunities for previously disenfranchised rural communities (Briedenhann \& Wickens, 2004). Teixeira and Ribeiro (2013) reported that a renewed interest in the food practices associated with the lamprey in rural Portugal led to a "retrenchment and revitalization of traditional means of capture, preparation, and consumption among the local and visiting populations" (p. 193).

Moreover, there has been an increased demand for recreational activities on farms over the last decades (Barbieri, Xu, Gil-Arroyo, \& Rich, 2016). The continued price drop of commodity crops also contributed to farm diversification, with about two-thirds of portfolio farmers (i.e., farmers with a diversified portfolio of income-generating farm-related businesses) in Texas reporting having diversified through agritourism (Barbieri \& Mahoney, 2009). However, the real importance of agritourism as a component of farm income is debatable (Chase, Stewart, Schilling, Smith, \& Walk, 2018; Schilling, Sullivan, \& Komar, 2012). For example, farmers may choose to charge visitors directly for leisure and educational activities, or use them as a loss leader to increase direct sales of produce or added-value products. According to Barbieri (2017), the wide range of activities falling under the umbrella of agritourism and the different strategies adopted by farmers to monetize them seem to hinder objective assessments of the real economic impact of agritourism.

Importantly, while farmers generally acknowledge important socioeconomic benefits from agritourism, they nonetheless identify primarily as farmers and take pride in welcoming visitors to a working farm (Tew \& Barbieri, 2012). For example, initiatives like Fork2Farmer encourage foodies to visit "authentic" local farms that supply the meat and produce consumed at high-end farm-to-table restaurants, while at the same time offering needed agritourism training to interested farmers (Morais, Jakes, Bowen, \& Lelekacs, 2017). However, more often than not, farmers do not have strong bridging ties with formal tourism business partners or small business development agencies to support them as they branch out into tourism-related services (Ferreira, 2018).

\section{Tourism Sharing Economy}

Small and microenterprises have struggled to make their goods and services visible to potential customers (Ferreira, Morais, \& Lorscheider, 2015). However, solutions that mediate information exchanges between suppliers and potential customers may disrupt the control exerted by formal distribution channels (Payton et al., 2015). Often, these solutions take the form of web marketplaces where microentrepreneurs can offer their services to potential customers. Marketplaces such as Airbnb, HipCamp, and Harvest Host allow suppliers to showcase their goods or services and help potential customers navigate offerings (DittaApichai et al., 2020; Ferreira et al., 2015).

However, Morais et al. (2012) contend that the economic power of the emerging sharing economy is largely being tapped by hyperconnected urbanites. Similarly, Baum (2006) suggests that the "digital divide"- the gap observed between individuals with ready access to information and communication technologies and those without such accessexacerbates social and economic discrepancies within societies. Therefore, web marketplaces are largely failing to engage under-resourced rural tourism microentrepreneurs who could benefit the most from alternative income sources to support 
their vulnerable livelihoods (Morais, Ferreira, Nazariadli, \& Gharamani, 2017).

\section{Tourism Microentrepreneurship}

Tourism microenterprises employ five or fewer employees and tend to operate in underregulated business environments that allow low entry barriers, but typically do not afford stable livelihoods or health benefits (Ferreira et al., 2015). Nevertheless, their small size and informal nature render microenterprises nimble and easily adaptable to the changing opportunities and challenges of business landscapes (Mladenovic, 2013). It should be noted that, in the scope of this paper, informality relates more to the range of informal arrangements (e.g., labor, channels, structure, nonmonetary exchange) than with the legal status of the firms (BoanadaFuchs \& Boanada Fuchs, 2018).

Tourism microentrepreneurship is the process of launching a new enterprise or adding value to an existing one, relying partially on web marketplaces to attract visitors and operating in any of the tourism sectors, employing no more than five people, with the aim to meet a market need and permitting the owner a desired livelihood and lifestyle (Ferreira et al., 2018). This definition helps differentiate de facto tourism microentrepreneurship (Gardiner \& Dolnicar, 2018; Morais, Ferreira, \& Wallace, 2017), from other microentrepreneurial activities performed in the context of tourism, such as management, maintenance, or cleaning services supporting the burgeoning web-based short-term accommodation rental market (Sigala \& Dolnicar, 2018). Thus, in this paper we refer to the former, that is, individuals who have a passion or hobby which they are willing to share with visitors in exchange for remuneration. These include microhoteliers (e.g., Airbnb.com, VRBO.com), providers of cultural experiences (e.g., PeopleFirstTourism. com, Vayable.com), or farmers offering farm-based recreational and educational experiences (e.g., Fork2Farmer.com).

In North Carolina, agritourism appears to be the most prominent expression of tourism microentrepreneurship, perhaps by capitalizing on the state's rich and diverse agriscape and its romantic appeal to urbanites seeking to celebrate local roots (Halim, Barbieri, Morais, Jakes, \& Seekamp, 2020;
Nazariadli, Morais, Bunds, Baran, \& Supak, 2019). Accordingly, the Visit NC Farms app currently lists nearly 800 agritourism assets (e.g., farm experiences, farm stays and lodging, tours and trails) and claims to reach close to 10,000 active users (Visit NC Farms, n.d.). Moreover, in a survey of 207 farms across North Carolina, Ferreira (2019) reported that the sales of farm experiences, tours, and stays to visitors were deemed at least very important by $45.4 \%$ of farmers, accounting for an estimated $14.4 \%$ of total farm income. Finally, agritourism offerings in the state may include a diverse set of educational, farm-based recreation, recreational self-harvest, hands-on, and other nonagricultural recreation (e.g., bounce castles, swings) activities (Brune, Knollenberg, Stevenson, Barbieri, \& Schroeder-Moreno (2020).

\section{Importance of Tourism Microentrepreneurship} According to McGehee and Kline (2008), microentrepreneurship is well suited to the context of rural tourism development, because it "harmonizes with the philosophy that problems are best solved by solutions generated from inside the community, and that external consultants are not needed to propose successful strategies for economic redemption" (p. 123). Likewise, many more authors have called for an increase in the stimulation and support of tourism microentrepreneurship by small business development authorities (Ferreira, 2016; K.C., 2015; LaPan, 2014; Mao, 2014; Nazariadli, 2018; Nyaupane, Morais \& Dowler, 2006).

The demand for authentic local tourism experiences (i.e., travel to non-touristy, off-thebeaten path, unspoiled places, and doing what locals do) has grown steadily over recent years (Destinations International, 2019; Week, 2012), but the question of who should train, organize, support, and promote these microentrepreneur providers of experiences remains largely unanswered (Morais, Ferreira, Nazariadli, \& Ghahramani, 2017). These and other tasks would normally fall under the local Tourism Development Authority (TDA) sphere of influence. However, the informal nature of these businesses coupled with the TDA's revenue model, largely dependent on the collection of "bed tax" from the formal hospitality sector, have been a hindrance to investment in the 
creation and nurture of networks of microentrepreneurs. With scarce institutional support and limited opportunities for role modeling, individuals may doubt their ability to become entrepreneurs and shy away from economic opportunities.

\section{Self-efficacy Theory}

Self-efficacy, defined as one's belief in one's ability to succeed in a target behavior, is a dominant theoretical paradigm used to explain people's motivation, effort, and perseverance in a task (Bandura, 1977). Self-efficacy theory holds that if people perceive themselves to be capable of accomplishing certain activities, they are more likely to undertake them in the future (Alkire, 2005). Moreover, self-efficacy will also influence an individual's level of motivation, as reflected in how much effort one will exert in a task, and how long one will persevere in the face of obstacles (Bandura, 1980). Ferreira et al. (2018) adapted the construct to the context of tourism microentrepreneurship, and developed the Tourism e-Microentrepreneurial Self-Efficacy (TeMSE) scale, which can be used to measure the five facets of the construct: Pursuing Innovation, Marshalling Resources, Adapting to Externalities, Aligning Core Purpose with Self, and e-Marketing (see Table 1). They defined TeMSE as one's belief in one's ability to successfully perform the various roles and tasks of microentrepreneurship in the tourism ebusiness sector.

It should be noted that one distinctive feature of self-efficacy theory is that, unlike other motivational theories, it is task-specific (Bandura, 1977). This is important because diversified farming is inherently entrepreneurial. Accordingly, McKee (2018) notes that small-scale farmers find themselves in a constant battle "to innovate new ways to distinguish themselves and their offerings, though successful strategies may then be taken up by competitors with more resources, forcing these farmers to innovate again" (p. 67). While these experiences may contribute to efficacy expectancies generalizable to other domains of the farmers' lives (Sherer et al., 1982), we argue that the roles and tasks of agritourism are significantly different from farming. Therefore, specific examination of TeMSE is both relevant and necessary for the purpose of this study.

\section{Training and Mentoring}

Compared to their urban counterparts, rural entrepreneurs may be at a disadvantage for a number of reasons, such as limited opportunities for financial capital and access to grants, insufficient transportation systems, local politics incompatible with entrepreneurial freedom, and lack of support networks and entrepreneurial role models (McGehee \& Kline, 2008). Accordingly, in the broad scope of entrepreneurship, mentoring has been identified as an effective vehicle for acquiring networking opportunities (Dymock, 1999), as well as elevating self-efficacy, validating one's entrepreneurial selfimage, and lowering a sense of solitude (St-Jean \& Audet, 2013).

Mentoring is a voluntary, committed, dynamic, extended, intensive, and supportive relationship characterized by trust, friendship, and mutuality between an experienced, respected person and a novice, with the purpose of socializing the latter in a new role and promoting self-efficacy (Hayes, 1998). Although mentoring has become a common practice in the tech start-up apparatus (Memon, Rozan, Ismail, Uddin, \& Daud, 2015), such an approach has not been deployed yet in the realm of tourism microentrepreneurship, certainly not systematically and not to scale. Accordingly, Halim (2016) called for the establishment of a system that would enable mentoring in rural areas, in which established entrepreneurs mentor young or start-up farm tourism microentrepreneurs. The absence of such a system seems to undermine the success of these ventures, especially when entrepreneurs find themselves on their own amidst a highly volatile regulatory environment and a changing economic landscape at the intersect of tourism, agriculture, and local politics (Halim, Morais, Barbieri, Jakes, \& Zering, 2016).

Although further research is needed to ascertain the effectiveness of a mentoring program under these specific conditions, the question we ask for the moment is who should start such a system? Who has privileged access to the communities and, more importantly, to the individuals who might choose to operate underground to survive the inquisitive arm of regulatory bodies? Who has the institutional framework to take this effort to scale? 
The Role of Cooperative Extension

Cooperative Extension is the largest outreach program at North Carolina State University, reaching millions of North Carolinians each year through local centers in the state's 100 counties plus in the Eastern Band of the Cherokee Indians (NC State Extension, n.d.). It was established through the Smith-Lever Act of 1914 with the aim of providing all citizens with access to the wealth of knowledge generated by public universities. It provides educational programming in five key areas, including maintaining viable communities, which seems to align well with opportunities for the economic rejuvenation of depressed rural areas enabled by new economies like tourism.

Given the role of Cooperative Extension in rural North Carolina, it is arguably the agency best positioned to establish and scale up a much-needed culture of entrepreneurial mentorship outside the state's urban centers. This may trigger a new set of questions: are extension field agents subjectknowledgeable to mentor tourism microentrepreneurship? Are they confident they could actually mentor farm tourism microentrepreneurs? In other words, are field agents efficacious in mentoring farm tourism microentrepreneurship?

While conventional entrepreneurial training has focused on business processes, from basic management practices to identifying and exploiting opportunities, Lucas and Cooper (2004) call for approaches that demystify the entrepreneurial process and build self-belief that aspiring entrepreneurs might have what it takes to succeed in business. The route we are exploring is mentorship. We propose that government agencies such as Cooperative Extension in North Carolina stand in a privileged position to take on the much-needed role of mentoring farm tourism microentrepreneurs.

Land-grant universities and Extension emerged from the growing need to have higher education available and geared toward the practical interests of common people (Key, 1996). In particular, Cooperative Extension provides educational programming in five areas: (1) sustaining agriculture and forestry; (2) protecting the environment, (3) maintaining viable communities; (4) developing responsible youth; and (5) developing strong, healthy and safe families. Efforts toward creating a vibrant tourism scene consisting of responsible locally owned businesses could foster any of these five areas in any given small town. Finally, Weber (1987) states that it is incumbent on Cooperative Extension to offer training curricula to increase the community's knowledge base with the goal of building local capacity. However, while we acknowledge the role of Extension and the dedication of its agents, there is some evidence that training curricula are adapted from formal business sectors and are not based on assessments of the rural tourism microentrepreneurs' specific needs (Ferreira, Morais, Bunds, \& Pollack, 2016). Also, as posited by Morais, Ferreira, Nazariadli, and Gharamani (2017), when the agency's efficiency is measured primarily by the number of clients (farmers) served, the incentive is for agents to deliver one-time workshops with large groups, in lieu of personalized accompaniment in the field, along the lines of mentoring.

The work of Cooperative Extension agents is even more important when we zoom out and consider the place that small farms and farmers occupy in the U.S. food system. Increased concentration of food production in the hands of partial oligopolies (Howard, 2016) and the financialization that prioritizes shareholder value over nutritious food and decent livelihoods, occlude social concerns as mere “externalities" (Clapp \& Isakson, 2018) and leave small farms and farmers in a vulnerable market position. As they cannot compete by price with the heavily subsidized, large-scale producers, these microentrepreneurs need to bet on quality and diversify their offer beyond the actual crops, to include knowledge as a product. Specifically, it is no longer enough for the microentrepreneur to advertise "local" produce, since large retailers such as Wal-Mart have moved in to capitalize on this label, alienating the actual producers (Bloom \& Hinrichs, 2017). Small producers then need to creatively adapt to such power imbalances, and it is here where the work of Extension agents can complete the puzzle: in inviting the foodies and the travelers to the farm, microentrepreneurs are at the forefront of agri-food movements that challenge the status quo of industrial food production, which alienates people from the land (Hinrichs \& 
Eshleman, 2014) and deskills consumers (Jaffe \& Gertler, 2006). Local entrepreneurs are key actors in rural development, but they need institutional and infrastructure support and an incentive structure that allows them to gain a foothold in the contested economic market (Dickes \& Robinson, 2014). Extension agents are in a position to offer the kind of assistance that allows microentrepreneurs to diversify their abilities and overcome institutional barriers.

\section{Purpose}

Tourism microentrepreneurship stands to be a critical mechanism through which host communities gain access to socio-economic benefits from tourism and may even gain a degree of control of the tourism development in their communities (Ditta-Apichai et al., 2020; LaPan, Morais, Wallace, \& Barbieri, 2016; Nazariadli et al., 2019). However, little is known about the process through which host community members become involved in tourism microentrepreneurship and about the ability of public systems to enable their growth and success. Accordingly, this study examines the microentrepreneurial self-efficacy of 29 farm tourism microentrepreneurs, as well as the perceived ability of local empowerment agents in the region to become mentors to those farmers. The purpose of this study was to identify areas in tourism microentrepreneurial activity where farmers could benefit from long-term accompaniment by Extension agents, as well as other areas where the flow of information could be in the opposite directionthat is, farmers may have accumulated experience and specific knowledge unknown to the agent. We hypothesize that this bidirectional flow of information could have two major implications:

(1) Increase the success of farm tourism enterprises, ${ }^{1}$ and

(2) Increase farm tourism specific knowledge of the Cooperative Extension institution.

\section{Methods}

This study is grounded in a strong emic perspective of rural and farm tourism microentrepreneurship, drawing on the team's extensive experience in the development of networks of microentrepreneurs in North Carolina. Part of this work was done in tandem with Extension agents, who nominated and introduced potential tourism microentrepreneurs in the community. This endorsement was instrumental because it granted us access to community members and dissipated suspicions about our intentions.

This study is composed of two complementary parts, which involved surveying two distinct populations using two different instruments. The first part refers to the measurement of tourism microentrepreneurial self-efficacy among 29 farmers in North Carolina, via phone. The second part refers to the measurement of mentoring self-efficacy among 54 extension agents, via an online survey. To make sense of the data, we plotted the results from both samples on a bidimensional matrix and compared the relative location of each pair of datapoints.

\section{Measuring TeMSE}

The development of the TeMSE scale was informed by longitudinal participatory actionresearch with rural tourism microentrepreneurs by Ferreira, Morais, Pollack, and Bunds (2018), and has been applied successfully to measure tourism microentrepreneurial self-efficacy of farmers (Ferreira, 2019). We administered the scale via phone to 29 farm tourism microentrepreneurs participating in the People-First Tourism project (P1t) in North Carolina, an initiative led by North Carolina State University with the aim of supporting individuals interested in pursuing sustainable livelihoods through tourism microentrepreneurship.

\footnotetext{
${ }^{1}$ Farm tourism enterprise success can be defined in a variety of ways beyond just profit. For example, in a study about women in agritourism, Halim (2016) found that in addition to general indicators of entrepreneurial success (e.g., contentment, peer-recognition), microentrepreneurs felt successful because agritourism also provided appreciative customers and ensured the perpetuation of their farms.
} 
Defining Tourism e-Microentrepreneurship Mentoring Self-Efficacy and Developing a Scale

The TeMSE questionnaire (i.e., the scale used to survey the 29 farmers) was modified to capture the new construct-Tourism e-Microentrepreneurship Mentoring Self-Efficacy-defined as one's belief in one's ability to successfully provide guidance and promote self-efficacy among tourism e-microentrepreneurs. Thus, the segment "I am able to..." which started all items of the TeMSE scale, was replaced with "I am able to provide guidance to microentrepreneurs on how to...". For example, TeMSE item "I am able to create experiences that fulfill tourists' interests" was changed to "I am able to provide guidance to microentrepreneurs on how to create experiences that fulfill tourists' interests." The scale was pilot tested with 24 participants in a statewide Cooperative Extension conference who registered for a workshop on tourism web marketplaces. No wording issues were detected, and item variances and means were within acceptable values.

\section{Measuring Tourism e-Microentrepreneurship Mentoring Self-Efficacy}

A link to an anonymous survey on Qualtrics was sent to select departments through the official NC Cooperative Extension listserv. Respondents selected themselves on the basis of whether their work entailed, to some extent, direct contact with farmers, artisans, storytellers, or entrepreneurs of any kind, as instructed in the e-mail message. To increase response rate, two follow-up emails were sent on different days of the week and different times. Fifty-four valid surveys were returned.

\section{Findings and Discussion}

\section{Farm Tourism Microentrepreneurs' Self-Efficacy}

Most respondents held either a bachelor's degree or postgraduate studies $(61 \%)$, there were more males $(71 \%)$, the average age was 54 years old, and Caucasian/White was the most prevalent ethnicity represented by far (64\%). The USDA (2017) statewide census of $\mathrm{NC}$ agriculture reports that $67 \%$ of farmers are male, averaging 58 years old, and predominantly White (94\%). Ten farmers reported not having any earnings from tourism at the time but were setting up to start receiving visitors. Average earnings from those who were currently offering experiences were $14 \%$ of their total livelihood.

In Table 1, it becomes apparent that elevating TeMSE dimensions Adapting to Externalities, eMarketing, and Marshalling Resources is a priority and warrants dedicated attention from rural development authorities, if farm tourism microentrepre-

Table 1. Descriptive Statistics and Reliability for Microentrepreneurs' TeMSE

\begin{tabular}{|c|c|c|c|c|}
\hline Dimension & Brief description & $\begin{array}{l}\text { Number } \\
\text { of Items }\end{array}$ & $\begin{array}{l}\text { Cronbach's } \\
\text { Alpha }\end{array}$ & Mean (1-5) \\
\hline Pursuing Innovation & $\begin{array}{l}\text { Striving for better ideas or methods, or integrating new } \\
\text { approaches that address ever changing market demands, } \\
\text { and improve competitive advantage }\end{array}$ & 2 & .49 & 4.18 \\
\hline Adapting to Externalities & $\begin{array}{l}\text { Capitalizing on or mitigating nuances in the legal landscape } \\
\text { affecting conditions the tourism sector that are out of their } \\
\text { control }\end{array}$ & 3 & .51 & 3.66 \\
\hline $\begin{array}{l}\text { Aligning Core Purpose } \\
\text { with Self }\end{array}$ & $\begin{array}{l}\text { Articulating to stakeholders a core purpose of the business } \\
\text { in line with personal idiosyncrasies and in support of a } \\
\text { desired lifestyle }\end{array}$ & 4 & .54 & 4.24 \\
\hline e-Marketing & $\begin{array}{l}\text { Effectively using social media and web applications to } \\
\text { market their businesses and engage with visitors and peers }\end{array}$ & 2 & .90 & 3.57 \\
\hline \multirow[t]{2}{*}{ Marshalling Resources } & $\begin{array}{l}\text { Assembling resources of different kinds (e.g., communal } \\
\text { labor, business partnerships, support from local agencies) } \\
\text { to support business }\end{array}$ & 3 & .50 & 3.67 \\
\hline & & & Mean & 3.86 \\
\hline
\end{tabular}


neurship is to fulfill its role of a powerful rejuvenator of underresourced areas.

Low values on Adapting to Externalities could reflect the ambiguity of information in respect to licenses, insurance, and taxes due for a tourism business. Airbnb is a good example: some cities have opted for full prohibition, whereas others have taken a laissez-faire approach (Nieuwland \& Van Melik, 2020); in specific jurisdictions, occupancy taxes are collected and paid automatically by the platform, while in others the microentrepreneur may need to collect them manually (Airbnb, n.d.). Regulatory ambiguity is apparent in a peculiar anecdote wherein one of the participating farmers was denied a lodging license for his log cabin by county authorities, but would be abiding by the law if he chose to rent it through Airbnb.

Some entrepreneurship theorists argue that the ability to adapt to change and leverage ambiguity are among the most important entrepreneurial skills (Moberg, 2013). Mladjenovic (2013), in the scope of microentrepreneurship, advises that being aware of taxes and other legal issues such as business structure (i.e., sole proprietorship, limited liability company, corporation, or partnership) is important to protect one's business interests. For example, until recently, outsourcing was considered unnecessary and too costly for microenterprises, but now is considered an available and affordable resource to save money and time and add efficiency to the venture.

Finally, e-Marketing, also shows a low mean value. ${ }^{2}$ Although it could be argued that the reason behind the low mean is the relatively old age of farmers in the sample, this argument falls short when one looks at the high education level, with $61 \%$ holding either a bachelor's degree or postgraduate studies. In fact, doing social media diligently can be a cumbersome task and take away from pressing tasks at hand (McKee, 2018). Doing it haphazardly undermines audience engagement and might lead to content becoming outdated, which can be perceived as sloppy management. However, if used judiciously, social media platforms such as Facebook, LinkedIn, and Twitter can help the microentrepreneur meet people and build relationships that in due course can translate into sales (Mladjenovic, 2013).

In order to reach underresourced tourism microentrepreneurs, Ferreira, Morais, and Lorscheider (2015) used the NC Cooperative Extension publication system to diffuse a fact sheet that explains in plain language how to use web marketplaces to reach untapped markets. Two hundred hard copies were distributed to a number of Cooperative Extension offices and local destination management organizations throughout the state, and a link was made available. ${ }^{3}$ In addition, the research team paired with leading Extension directors to deliver train-the-trainer workshops to field agents, with the purpose of elevating the agents' tourism e-microentrepreneurship mentoring self-efficacy, enhancing and multiplying the impact of the research.

The results on Marshalling Resources seem to capture farmers' difficulty in getting the institutional support necessary to validate their business and grant access to financial resources, certifications, training, and expertise. Halim (2016) found this struggle to be even harder among women farm tourism microentrepreneurs, as they lack the resources and credibility as farmers while at the same time juggling traditional roles. Secondly, there might be some concern and mistrust from other local businesses that might undermine the strengthening of bonds between tourism businesses and those in the primary and secondary sectors. For example, Nyaupane, Morais, and Dowler (2006) reported a disruption of traditional kinship and community bonds, in particular conflict and disharmony, between lodge owners and farmers in a tourist destination in Nepal. Finally, the unavailability of helpers when the need arises might have to do with the seasonal character of tourism and that demand is stronger on weekends and holidays. Halim, Morais, Barbieri, Jakes, and Zering (2016) found the latter to be the most prominent challenge among women in agritourism in North Carolina, for it adds to their already heavy burden of work, which keeps them from investing in long-

2 While contextual factors such as rural broadband issues may play a role, they are outside the scope of this paper.

3 http://content.ces.ncsu.edu/using-web-marketplaces-to-reach-untapped-markets 
term planning for the farm and thus hinders their capacity to harness its growth potential.

Some authors have proposed strategies to overcome the inability to marshal resources among rural microentrepreneurs. Morais, Ferreira, Nazariadli, and Ghahramani (2017) described how P1t microentrepreneurs are organized in networks that promote both cooperation and competition, or "co-opetition" (Nalebuff \& Brandenburger, 1997), to improve social capital, namely bonding ties between microentrepreneurs, and bridging ties with organizations and partners that might bring them opportunities and access to resources not readily available within the network (Narayan \& Cassidy, 2001).

\section{Agents Mentoring Self-Efficacy}

Data from the survey with Extension agents revealed that the majority of respondents $(70 \%)$ were White, $43 \%$ were aged between 50 and 59 years, and $54 \%$ were male. Regarding time spent face-to-face with microentrepreneurs (i.e., in-person interaction with one individual or a small group), 35 of 54 respondents reported spending less than $20 \%$ of their working hours, whereas only 9 reported spending more than $50 \%$ interacting directly with microentrepreneurs (Figure 1). These sobering figures are consistent with Ensle's (2005) assertion that agent's "enjoyment of teaching and working with the public often gets sidelined for endless paperwork with unrealistic due dates" (para. 2).

The relatively small sample size unfortunately did not enable a thorough exploration of the underlying structure and relationships between variables. However, the exceptionally high alphas (Santos, 1999) found in the sample of mentors reveal great dimension consistency and anticipate an underlying structure identical of the structure of the original scale (Table 2).

\section{Microentrepreneurship Mentoring Matrix}

To ascertain whether agents are equipped and confident to mentor their clients, or, in other words, are "able to provide guidance to microentrepreneurs," we developed the Microentrepreneurship Mentoring Matrix $\left(\mathrm{M}^{3}\right)$. This tool is loosely adapted from the performance-importance analysis, a framework used extensively in hospitality and tourism research because of its simplicity (Lai \& Hitchcock, 2015). The $\mathrm{M}^{3}$ analyzes quality attributes on two dimensions, in this case microentrepreneurs' and mentors' self-efficacy. These dimensions are then integrated into a matrix that helps to identify pressing training needs in the field and devise the most appropriate strategic options to overcome them. Moreover, the $\mathrm{M}^{3}$ can be defined by orthogonal axes that intercept at mean values of TeMSE and TeMSE-Mentor, creating four quadrants that inform four different strategies of intervention depending where the data points fall:

\section{Figure 1. Percent of Working Time Spent Mentoring Microentrepreneurs Face to Face}

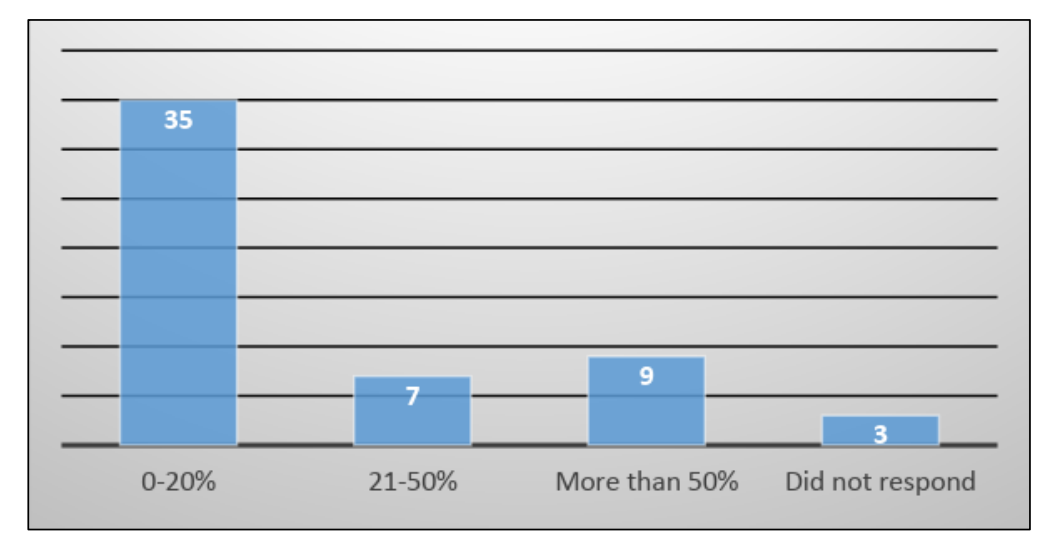

Table 2. Descriptive Statistics and Reliability for Mentors' TeMMentSE

\begin{tabular}{lccc}
\hline Dimension & $\begin{array}{c}\text { Number } \\
\text { of Items }\end{array}$ & $\begin{array}{c}\text { Cronbach's } \\
\text { Alpha }\end{array}$ & Mean \\
\hline Pursuing Innovation & 2 & .90 & 3.38 \\
Adapting to Externalities & 3 & .87 & 2.40 \\
Aligning Core Purpose with Self & 4 & .91 & 3.28 \\
e-Marketing & 2 & .91 & 3.17 \\
Marshalling Resources & 3 & .78 & 3.25 \\
\hline
\end{tabular}


(1) Outreach: Mentors are self-efficacious whereas microentrepreneurs are not; need for top-down flow of knowledge.

(2) Inreach: Microentrepreneurs are selfefficacious but mentors are not; opportunity for bottom-up flow of knowledge.

(3) Train the mentor: Neither mentors nor microentrepreneurs are self-efficacious; training the mentors has a multiplier effect, increasing the number of microentrepreneurs exposed to applied research.

(4) Low priority: Both mentors and microentrepreneurs are self-efficacious; resources should be directed to other areas.

Analysis of the $\mathrm{M}^{3}$ (Figure 2) allows us to clearly discern that the pairs TeMSE/TeMSE-
Mentor fall under three distinct categories, namely Outreach, Low Priority, and Train the Mentor. The data also indicate that there is not a category in which tourism microentrepreneurs are sufficiently self-efficacious to enable inreach to agents, that is, a bottom-up distribution of entrepreneurial knowledge that would serve the agents in future mentoring occasions.

Pursuing Innovation and Aligning Core Purpose with Self are areas of least concern. The already reported high level of ingenuity of microentrepreneurs, as well as their strong ability to create and run a venture that encompasses their idiosyncrasies, are matched by the agents' mentoring self-efficacy in these dimensions.

Conversely, the dimension Adapting to Externalities is a matter of high concern because neither

Figure 2. Microentrepreneurship Mentoring Matrix

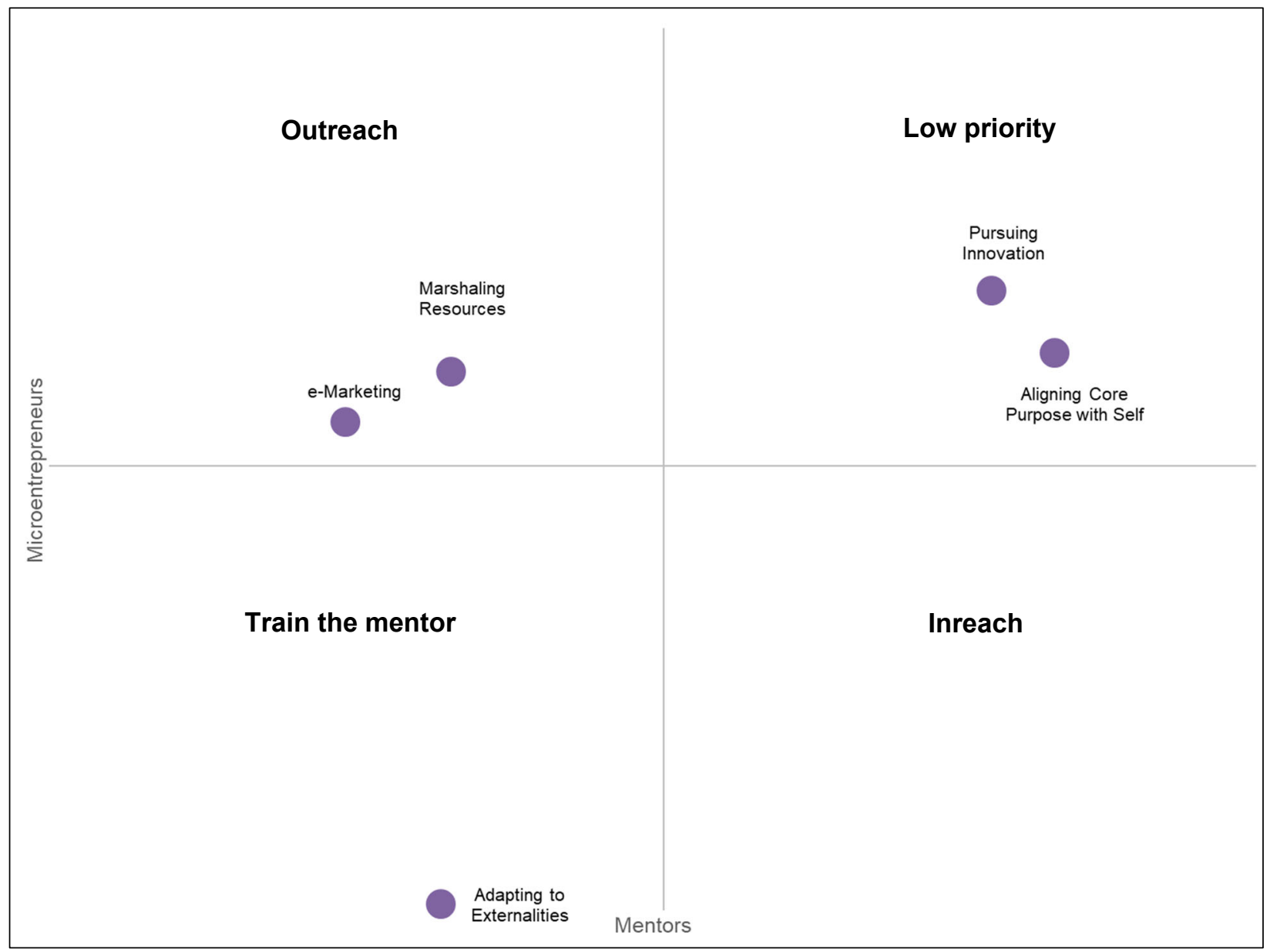


farmers nor mentors believe they are efficacious. Here, the specificity of tourism in the marketplace and the particular, often ambiguous, legal framework it falls under might contribute to the low values of mentoring self-efficacy reported by mentors, who have been trained and are experienced in other more traditional rural economic activities such as agriculture, forestry, or fishery. Furthermore, our experience engaging with Extension agents suggests that they are generally apprehensive to comment on topics that may be related to farm liability and permitting because there is ambiguity about these topics and they have very tangible consequences to the welfare of the microentrepreneurs they mentor. Considering that Extension agents are public employees, they are naturally very apprehensive to provide advice about these topics out of concern that it might get them into legal trouble. In North Carolina this gap has been partially filled by agritourism associations that invite insurance agencies to give presentations about their products during meetings and provide lists of insurance agencies interested in selling products for this kind of risk protection. In addition, academic programs engaged with this population (e.g., P1tLab) periodically invite county and municipality permitting authorities to informal microentrepreneur gatherings with the goal of providing clarification about applicable policies and enforcement in a nonthreatening context.

The third and last category, Outreach, comprises the dimensions Marshalling Resources and $e$ Marketing. Here, mentors appear to be slightly more efficacious than farmers; therefore, in these areas, Extension mentors seem already qualified to support farm tourism microenterprises. Accordingly, agents should think of themselves as contacts who can connect farmers with key local leaders, grants, and support services that can enable microentrepreneurial success in the form of access to new markets, partnerships with formal sector companies, funding, or help with marketing efforts. Likewise, by virtue of the intense online component of Extension agents' work, they are generally wellpositioned to mentor farmers on how to use social media effectively to connect with current and potential customers. In addition, agents can establish virtual networks of local farmers to fuel communication between members for enhanced intragroup support and to efficiently disseminate information among them.

Results from this study confirm the innovative character of current small-scale farming, as farmers are pushed to diversify their agricultural and nonagricultural offerings, explore new markets, and stay relevant in the local foods scene (McKee, 2018; Mikko Vesala, Peura, \& McElwee, 2007). For farmers, agritourism is an expansion of their selves, a stage where they have a voice and a devoted audience (Nazariadli et al., 2019), and a meaningful and rewarding way to enable a desired lifestyle (Ateljevic \& Doorne, 2000; Barbieri, 2017). Whereas innovation, passion, and meaning abound among farmers, many still struggle to effectively deal with liability, secure resources from a variety of sources, and make effective use of web marketplaces.

Extension agents are recognized by farmers involved in agritourism as a reliable source of assistance (Halim et al., 2020). Results also seem to indicate that agents, in general, are comfortable in such role, denoting the necessary skills, means, and disposition to act as mentors. This is encouraging because, in theory, agents can be effective sources of guidance in matters related to two of the lowestscoring dimensions among farmers. These are arguably the two most important areas in the feasibility of an agritourism venture: the ability to marshal resources and the ability to reach out to customers.

\section{Conclusions}

Farm tourism microentrepreneurship has great potential for rural development. It brings in new money to those most likely to spend it locally, it builds opportunities for place-based work and income generation, it provides the authenticity demanded by urbanites looking for genuine experiences of knowledge, people, and places different from their own. As agribusinesses differentiate themselves to include the provision of lodging, experiences, and food products to tourists, so does Extension's role expand to encompass mentoring of tourism microentrepreneurship. This study reveals the specific needs and competencies of farm tourism microentrepreneurs and contrasts 
those with the mentoring capabilities of Extension agents. This is the first study of this kind; therefore, the findings provide only initial insight into the mentoring context in rural North Carolina.

One apparent limitation of this study is the low size of the sample of farm tourism microentrepreneurs. This, of course, is a consequence of our resolve to administer the survey via phone in order to include individuals whose perspectives would likely be excluded had we opted for online surveying. Also, modest reliability scores on some of the TeMSE dimensions suggest that the scale may need refinement for application in the context of farm tourism, and thus prudence is recommended when considering scores for each dimension.

More research exploring needs and Extension programs and resources should follow, in North Carolina and in other regions. Additionally, a similar approach to study mentoring gaps should be employed in contexts markedly different from North Carolina where other kinds of organizations (e.g., international NGOs) fill in the role of developing local tourism capacity.
The COVID-19 pandemic supershock brought the entire service industry to its knees, but small and microbusinesses have been affected the most (Bartik et al., 2020; Fairlie, 2020). Moving forward, as authorities implement recovery plans and make resources available for microentrepreneurs, we argue that mentorship can play an important role in accelerating entrepreneurial action (Bacq, Geoghegan, Josefy, Stevenson, \& Williams, 2020).

Overall, it is noteworthy that this study departs from traditional tourism capacity-building approaches that have focused on training local people for qualified hospitality employment (see Hoefle, 2016; Massyn, 2008; and Nepal, 2007). Contrary to earlier tourism research paradigms limited to exploring ways for local people to passively support a tourism industry primarily concerned with meeting demand, this study subscribes to the Manifesto of the People-First Tourism Movement (Morais, 2017) that advocates research that advances ways for local people to harness the economic muscle of tourism in their own terms through tourism microentrepreneurship.

\section{References}

Airbnb. (n.d.). How does occupancy tax collection and remittance by Airbnb work? Retrieved October 29, 2020, from https://www.airbnb.com/help/article/1036/how-does-occupancy-tax-collection-and-remittance-by-airbnb-work

Alkire, S. (2005). Subjective quantitative studies of human agency. Social Indicators Research, 74(1), 217-260. https://doi.org/10.1007/s11205-005-6525-0

Ateljevic, I., \& Doorne, S. (2000). 'Staying within the fence': Lifestyle entrepreneurship in tourism. Journal of Sustainable Tourism, 8(5), 378-392. https://doi.org/10.1080/09669580008667374

Bacq, S., Geoghegan, W., Josefy, M., Stevenson, R., \& Williams, T. A. (2020). The COVID-19 Virtual Idea Blitz: Marshaling social entrepreneurship to rapidly respond to urgent grand challenges. Business Horizons, 63(6), 705-723. https://doi.org/10.1016/j.bushor.2020.05.002

Bandura, A. (1977). Self-efficacy: Toward a unifying theory of behavioral change. Psychological Review, 84(2), $191-215$. https://doi.org/10.1037/0033-295X.84.2.191

Bandura, A. (1980). Gauging the relationship between self-efficacy judgment and action. Cognitive Therapy and Research, 4(2), 263-268. https://doi.org/10.1007/BF01173659

Barbieri, C. (2017). Agroturismo e desenvolvimento rural sustentável: o enfoque sistêmico do agroturismo. In K. Solha, I. Elesbão, \& M. de Souza (Eds.), O Turismo rural comunitários como estratégia de desenvolvimento (pp. 19-44). Porto Alegre, Brazil: Editora da UFRGS.

Barbieri, C., \& Mahoney, E. (2009). Why is diversification an attractive farm adjustment strategy? Insights from Texas farmers and ranchers. Journal of Rural Studies, 25(1), 58-66. https://doi.org/10.1016/j.jrurstud.2008.06.001

Barbieri, C., Xu, S., Gil-Arroyo, C., \& Rich, S. R. (2016). Agritourism, farm visit, or...? A branding assessment for recreation on farms. Journal of travel research, 55(8), 1094-1108. https://doi.org/10.1177/0047287515605930

Bartik, A. W., Bertrand, M., Cullen, Z., Glaeser, E. L., Luca, M., \& Stanton, C. (2020). The impact of COVID-19 on small business outcomes and expectations. Proceedings of the National Academy of Sciences, 117(30), 17656-17666. https://doi.org/10.1073/pnas.2006991117 
Baum, T. (2006). Low-cost air travel: Social inclusion or social exclusion? Tourism Culture \& Communication, 7(1), 49-56. https://doi.org/10.3727/109830406778493524

Bloom, J. D., \& Hinrichs, C. C. (2017). The long reach of lean retailing: Firm embeddedness and Wal-Mart's implementation of local produce sourcing in the US. Environment and Planning A: Economy and Space, 49(1), $168-185$. https://doi.org/10.1177/0308518X16663207

Boanada-Fuchs, A., \& Boanada Fuchs, V. (2018). Towards a taxonomic understanding of informality. International Development Planning Review, 40(4), 397-420. https://doi.org/10.3828/idpr.2018.23

Briedenhann, J., \& Wickens, E. (2004). Tourism routes as a tool for the economic development of rural areas—vibrant hope or impossible dream? Tourism Management, 25(1), 71-79. https://doi.org/10.1016/S0261-5177(03)00063-3

Brune, S., Knollenberg, W., Stevenson, K. T., Barbieri, C., \& Schroeder-Moreno, M. (2020). The influence of agritourism experiences on consumer behavior toward local food. Journal of Travel Research. Advance online publication. https://doi.org/10.1177/0047287520938869

Carneiro, M. J., Lima, J., \& Silva, A. L. (2018). Landscape and the rural experience: Identifying key elements, addressing potential, and implications for the future. In B. Lane \& E. Kastenholz (Eds.), Rural tourism: New concepts, new research, new practice (pp. 1236-1256). New York: Routledge.

Chase, L. C., Stewart, M., Schilling, B., Smith, B., \& Walk, M. (2018). Agritourism: Toward a conceptual framework for industry analysis. Journal of Agriculture, Food Systems, and Community Development, 8(1), 13-19. https://doi.org/10.5304/jafscd.2018.081.016

Clapp, J., \& Isakson, S. R. (2018). Risky returns: The implications of financialization in the food system. Development and Change, 49(2), 437-460. https://doi.org/10.1111/dech.12376

Cunha, C., Kastenholz, E. \& Carneiro, M. J. (2011). Análise da relevância do empreendedorismo estilo de vida para o desenvolvimento na oferta de turismo em espaço rural. In. E. Figueiredo (Ed.), O rural plural: Olhar o presente, imaginar o futuro (pp. 203-214). Castro Verde, PT: 100Luz.

Destinations International. (2019). Destination NEXT Futures Study 2019: A strategic road map for the next generation of global destination organizations [Technical report]. Retrieved from https://destinationsinternational.org/sites/default/master/files/DestinationNEXT\%202019 v2.pdf

Dickes, L. A., \& Robinson, K. L. (2014). Rural entrepreneurship. In C. Bailey, L. Jensen, \& E. Ransom (Eds.), Rural America in a Globalizing World: Problems and Prospects for the 2010s (pp. 591-608). Morgantown: West Virginia University Press.

Ditta-Apichai, M., Kattiyapornpong, U., \& Gretzel, U. (2020). Platform-mediated tourism micro-entrepreneurship: implications for community-based tourism in Thailand. Journal of Hospitality and Tourism Technology. Advance online publication. https://doi.org/10.1108/JHTT-05-2019-0079

Dymock, D. (1999). Blind date: A case study of mentoring as workplace learning. Journal of Workplace Learning, 11(8), 312-317. https://doi.org/10.1108/13665629910300496

Ensle, K. M. (2005). Burnout: How does Extension balance job and family? Journal of Extension, 43(3), 3FEA5. Retrieved from https://www.joe.org/joe/2005june/a5.php

Fairlie, W. R. (2020). The impact of COVID-19 on small business owners: Evidence of early stage losses from the April 2020 current population survey (Working Paper 27309). Cambridge, MA: National Bureau of Economic Research. https://doi.org/10.3386/w27309

Ferreira, B. M. S. (2016). Development and validation of the Tourism e-Microentrepreneurial Self-Efficacy Scale (Masters thesis). North Carolina State University, Raleigh, USA. Retrieved from http://www.lib.ncsu.edu/resolver/1840.16/11385

Ferreira, B. S. (2018). From farm-to-fork to fork-to-farmer: Advancing permatourism in North Carolina. Paper Presented at the 49"th Travel and Tourism Research Association International Conference. Retrieved from https://scholarworks.umass.edu/ttra/2018/Grad Student Workshop/7

Ferreira, B. M. S. (2019). Permatourism: Concept development, application and empirical validation (Doctoral dissertation). North Carolina State University, Raleigh, North Carolina, USA. Retrieved from https://search.proquest.com/docview/2380641461?pq-origsite=gscholar\&fromopenview $=$ true 
Ferreira, B. S., Morais, D. B., Pollack, J. M., \& Bunds, K. S. (2018). Development and validation of the tourism emicroentrepreneurial self-efficacy scale. Tourism Analysis, 23(2), 275-282. https://doi.org/10.3727/108354218X15210313504616

Ferreira, B., Morais, D., \& Lorscheider M. (2015). Using web marketplaces to reach untapped markets (North Carolina Cooperative Extension Publication AG-811). Retrieved from https://content.ces.ncsu.edu/show_ep3_pdf/1540576623/23020/

Ferreira, B., Morais, D., Bunds, K., \& Pollack, J. (2016, April 4). Mentoring tourism e-microentrepreneurship: The Self-Efficacy Scale for rural development change agents. Oral presentation at the Northeastern Recreation Research Conference. Maryland, MD.

Gardiner, S., \& Dolnicar, S. (2018). Will networks become one-stop travel shops? In S. Dolnicar (Ed.), Peer-to-peer accommodation networks: Pushing the boundaries (pp. 87-97). Oxford: UK: Goodfellow Publishers. https://doi.org/10.23912/9781911396512-3606

Halim, M. F. (2016). Ushering NC women in agritourism towards success: Challenges and Opportunities (Master's thesis). North Carolina State University, USA. Retrieved from http://www.lib.ncsu.edu/resolver/1840.16/11062

Halim, M. F., Barbieri, C., Morais, D. B., Jakes, S., \& Seekamp, E. (2020). Beyond economic earnings: The holistic meaning of success for women in agritourism. Sustainability, 12(12), 4907. https://doi.org/10.3390/su12124907

Halim, M. F., Morais, D. B., Barbieri, C., Jakes, S., \& Zering, K. (2016, June). Challenges faced by women entrepreneurs involved in agritourism. Proceedings from the 47th Tourism and Travel Research Association Conference. Vail, Colorado, USA. Retrieved from https://scholarworks.umass.edu/ttra/2016/Academic Papers Oral/10/

Hayes, E. F. (1998). Mentoring and nurse practitioner student self-efficacy. Western Journal of Nursing Research, 20(5), 521-535. https://doi.org/10.1177/019394599802000502

Hinrichs, C., \& Eshleman, J. (2014). Agrifood movements: Diversity, aims, and limits. In C. Bailey, L. Jensen, \& E. Ransom (Eds.), Rural America in a Globalizing World: Problems and Prospects for the 2010s (pp. 138-155). Morgantown, WV: West Virginia University Press.

Hoefle, S. W. (2016). Multi-functionality, juxtaposition and conflict in the Central Amazon: Will tourism contribute to rural livelihoods and save the rainforest? Journal of Rural Studies, 44, 24-36. https://doi.org/10.1016/j.jrurstud.2015.12.009

Howard, P. H. (2016). Concentration and power in the food system: Who controls what we eat? (Vol. 3). New York: Bloomsbury. https://doi.org/10.5040/9781474264365

Hustedde, R. J. (2018). Entrepreneurship and economic development in rural America. In D. A. Harley, N. A. Ysasi, M. L. Bishop, \& A. R. Fleming (Eds.), Disability and Vocational Rehabilitation in Rural Settings (pp. 3-16). Cham, Switzerland: Springer. https://doi.org/10.1007/978-3-319-64786-9 1

Jaffe, J., \& Gertler, M. (2006). Victual vicissitudes: Consumer deskilling and the (gendered) transformation of food systems. Agriculture and Human Values, 23(2), 143-162. https://doi.org/10.1007/s10460-005-6098-1

K.C., B. (2015). Examining networks, social capital, and social influence among wildlife tourism micro-entrepreneurs in coastal North Carolina (Doctoral dissertation). North Carolina State University, USA. Retrieved from http://www.lib.ncsu.edu/resolver/1840.16/10783

Key, S. (1996). Economics or education: The establishment of American land-grant universities. The Journal of Higher Education, 67(2), 196-220. https://doi.org/10.2307/2943980

Lai, I. K. W., \& Hitchcock, M. (2015). Importance-performance analysis in tourism: A framework for researchers. Tourism Management, 48, 242-267. https://doi.org/10.1016/j.tourman.2014.11.008

Lane, B. (1994). What is rural tourism? Journal of Sustainable Tourism, 2(1-2), 7-21. https://doi.org/10.1080/09669589409510680

LaPan, C. M. (2014). Communitarian micro-entrepreneurship and gender in the Maya touristscape (Doctoral dissertation). North Carolina State University, USA. Retrieved from http://www.lib.ncsu.edu/resolver/1840.16/9430

LaPan, C., Morais, D. B., Wallace, T., \& Barbieri, C. (2016). Women's self-determination in cooperative tourism microenterprises. Tourism Review International, 20(1), 41-55. https://doi.org/10.3727/154427216X14581596799022

Lucas, W. A., \& Cooper, S. Y. (2004). Enhancing self-efficacy to enable entrepreneurship: The case of CMI's connections (MIT Sloan Working Paper No. 4489-04). https://doi.org/10.2139/ssrn.568383 
Mao, Y. (2014). Spatial analysis of tourism micro-entrepreneurship and poverty in North Carolina and its neighboring states (Doctoral dissertation). North Carolina State University, USA. Retrieved from http://www.lib.ncsu.edu/resolver/1840.16/10011

Massyn, P. J. (2008). Citizen participation in the lodge sector of the Okavango Delta. In A. Spenceley (Ed.), Responsible tourism: Critical issues for conservation and development (pp. 225-238). London: UK Earthscan.

McGehee, N. G., \& Kline, C. S. (2008). Entrepreneurship and the rural tourism industry: A primer. In G. Moscardo (Ed.), Building Community Capacity for Tourism Development (pp. 123-141). CABI. https://doi.org/10.1079/9781845934477.0123

McKee, E. (2018). "It's the Amazon world": Small-scale farmers on an entrepreneurial treadmill. Culture, Agriculture, Food and Environment, 40(1), 65-69. https://doi.org/10.1111/cuag.12107

Memon, J., Rozan, M. Z. A., Ismail, K., Uddin, M., \& Daud, D. (2015). Mentoring an Entrepreneur: Guide for a mentor. SAGE Open, 5(1). https://doi.org/10.1177/2158244015569666

Mikko Vesala, K., Peura, J., \& McElwee, G. (2007). The split entrepreneurial identity of the farmer. Journal of Small Business and Enterprise Development, 14(1), 48-63. https://doi.org/10.1108/14626000710727881

Mladjenovic, P. (2013). Micro-entrepreneurship for dummies. Hoboken, NJ: John Wiley \& Sons.

Moberg, K. (2013). An entrepreneurial self-efficacy scale with a neutral wording. In A. Fayolle, P. Kyrö, T. Mets, \& U. Venesaar (Eds.), Conceptual Richness and Methodological Diversity in Entrepreneurship Research: Entrepreneurship Research in Europe (pp. 67-94). London: Edward Elgar.

Morais, D. B. (2017). Manifesto of the People-First Tourism Movement (Report No. P1tLab 2017-004). https://doi.org/10.13140/RG.2.2.15992.24329

Morais, D. B., Ferreira, B. S., Nazariadli, S., \& Ghahramani, L. (2017). Knowledge co-generation and transfer in the People-First Tourism project. In N. Scott, M. De Martino, \& M. Van Niekerk (Eds.), Bridging Tourism Theory and Practice, Vol. 8 (pp. 73-96). London: Emerald. https://doi.org/10.1108/S2042-144320170000008006

Morais, D., Ferreira, B., \& Wallace, T. (2017). Aprendizagem Aplicada e Investigação-Acção Participativa através do Projecto People-First Tourism: Uma visão geral de métodos e instrumentos [Applied learning and participatory action research through the People-First Tourism Project: An overview of methods and instruments]. In K. Solha, I. Elesbão, \& M. de Souza (Eds.), O Turismo rural comunitários como estratégia de desenvolvimento [Community rural tourism as a development strategy] (pp. 87-114). Porto Alegre, Brazil: Editora da UFRGS.

Morais, D. B., Heath, E., Tlhagale, M., Payton, F. C., Martin, K., Mehta, K., \& Bass, J. (2012). People-First Tourism. In E. Fayos-Sola, Silva, J., \& Jafari, J. (Eds.). Knowledge Management in Tourism: Policy and Governance Applications. Bridging Tourism Theory and Practice, Volume 4 (pp. 115-128). London: Emerald. https://doi.org/10.1108/S2042-1443(2012)0000004009

Morais, D., Jakes, S., Bowen, B., \& Lelekacs, J. M. (2017). Fork2Farmer: Enabling success of small farms through partnerships with well-known chefs and the tourism sector. Journal of Extension, 55(2), v55-2iw3. Retrieved from https://www.joe.org/joe/2017april/iw3.php

Nalebuff, B. J., \& Brandenburger, A. M. (1997). Co-opetition: Competitive and cooperative business strategies for the digital economy. Strategy \& Leadership, 25(6), 28-33. https://doi.org/10.1108/eb054655

Narayan, D., \& Cassiday, M. F. (2001). A dimensional approach to measuring social capital: Development and validation of a social capital inventory. Current Sociology, 49(2), 59-102. https://doi.org/10.1177/0011392101049002006

Nazariadli, S. (2018). An urbannormative and Orientalist critique of the representational bias in rural tourism (Doctoral dissertation). North Carolina State University, USA. Retrieved from http://www.lib.ncsu.edu/resolver/1840.20/35092

Nazariadli, S., Morais, D. B., Bunds, K., Baran, P., \& Supak, S. (2019). Rural tourism microentrepreneurs' selfrepresentation through photography: A counter-hegemonic approach. Rural Society, 28(1), 29-51. https://doi.org/10.1080/10371656.2019.1576294

NC State Extension. (n.d.). NC State Extension. Retrieved October 29, 2020, from https://www.ces.ncsu.edu/

Nepal, S. K. (2007). Tourism and rural settlements: Nepal's Annapurna region. Annals of Tourism Research, 34(4), 855-875. https://doi.org/10.1016/j.annals.2007.03.012 
Nieuwland, S., \& van Melik, R. (2020). Regulating Airbnb: How cities deal with perceived negative externalities of shortterm rentals. Current Issues in Tourism, 23(7), 811-825. https://doi.org/10.1080/13683500.2018.1504899

Nyaupane, G. P., Morais, D. B., \& Dowler, L. (2006). The role of community involvement and number/type of visitors on tourism impacts: A controlled comparison of Annapurna, Nepal and Northwest Yunnan, China. Tourism Management, 27(6), 1373-1385. https://doi.org/10.1016/j.tourman.2005.12.013

Organization for Economic Cooperation and Development [OECD]. (2003). Entrepreneurship and local economic development: Programme and policy recommendations. Paris: OECD. Retrieved from https://www.oecd.org/cfe/leed/entrepreneurshipandlocaleconomicdevelopmentprogrammeandpolicyrecommenda tions.htm

OECD. (2016). OECD tourism trends and policies 2016. Paris: OECD Publishing. http://dx.doi.org/10.1787/tour-2016-en

Payton, F. C., Morais, D. B., \& Heath, E. (2015). Multi-stakeholder assessment of a mobile and temporarily interconnected systems prototype: People-First Tourism. The African Journal of Information Systems, 7(1), 21-39. Retrieved from https://digitalcommons.kennesaw.edu/ajis/vol7/iss1/2

Santos, J. R. A. (1999). Cronbach's alpha: A tool for assessing the reliability of scales. Journal of Extension, $37(2), 2$ TOT3. Retrieved from https://www.joe.org/joe/1999april/tt3.php

Schilling, B. J., Sullivan, K. P., \& Komar, S. J. (2012). Examining the economic benefits of agritourism: The case of New Jersey. Journal of Agriculture, Food Systems, and Community Development, 3(1), 199-214. https://doi.org/10.5304/jafscd.2012.031.011

Sharpley, R., \& Sharpley, J. (1997). Rural tourism. An introduction. Press. London, UK: International Thomson Business.

Sherer, M., Maddux, J. E., Mercandante, B., Prentice-Dunn, S., Jacobs, B., \& Rogers, R. W. (1982). The self-efficacy scale: Construction and validation. Psychological Reports, 51(2), 663-671. https://doi.org/10.2466/pr0.1982.51.2.663

Sigala, M., \& Dolnicar, S. (2018). Entrepreneurship opportunities. In S. Dolnicar (Ed.), Peer-to-Peer Accommodation Networks: Pushing the Boundaries (pp. 77-86). Oxford: UK: Goodfellow Publishers. https://doi.org/10.23912/9781911396512-3605

St-Jean, E., \& Audet, J. (2013). The effect of mentor intervention style in novice entrepreneur mentoring relationships. Mentoring \& Tutoring: Partnership in Learning, 21(1), 96-119. https://doi.org/10.1080/13611267.2013.784061

Teixeira, V. A. V., \& Ribeiro, N. F. (2013). The lamprey and the partridge: A multi-sited ethnography of food tourism as an agent of preservation and disfigurement in Central Portugal. Journal of Heritage Tourism, 8(2-3), 193-212. https://doi.org/10.1080/1743873X.2013.767813

Tew, C., \& Barbieri, C. (2012). The perceived benefits of agritourism: The provider's perspective. Tourism Management, 33(1), 215-224. https://doi.org/10.1016/j.tourman.2011.02.005

U.S. Department of Agriculture. (2017). 20917 Census of Agriculture: State Profile: North Carolina. Retrieved from https://www.nass.usda.gov/Publications/AgCensus/2017/Online Resources/County Profiles/North Carolina/c p99037.pdf

Vafadari, K. (2013). Exploring tourism potential of agricultural heritage systems: A case study of the Kunisaki Peninsula, Oita Prefecture, Japan. Issues in Social Science, 1(1), 33-51. https://doi.org/10.5296/iss.v1i1.4465

Visit NC Farms. (n.d.). How does it work? Retrieved October 29, 2020, from https://visitncfarmstoday.com/faq-1

Weber, B. A. (1987). Extension's roles in economic development. Journal of Extension, 25(1), 1FEA5. Retrieved from https://www.joe.org/joe/1987spring/a5.php

Week, L. (2012). I am not a tourist: Aims and implications of “traveling." Tourist Studies, 12(2), 186-203. https://doi.org/10.1177/1468797612454627 